ERHARD CZIOMER

Krakowska Akademia im. A. Frycza-Modrzewskiego

DOI : 10.14746/rie.2016.10.6

\title{
Wybrane implikacje wzrostu międzynarodowej roli Niemiec dla współpracy z Rosją i Polską w dobie globalizacji i kryzysów Unii Europejskiej w XXI wieku
}

\begin{abstract}
Wstęp
Celem artykułu jest przedstawienie wybranych implikacji wzrostu międzynarodowej roli Niemiec dla współpracy z Rosją i Polską na tle kryzysów Unii Europejskiej (UE) w dobie globalizacji XXI w. Opracowanie koncentruje się w ujęciu syntetycznym oraz problemowym na analizie następujących zagadnień:

- istota kształtowania koncepcji nowej roli międzynarodowej Niemiec,

- ogólna ocena roli Niemiec w próbach rozwiązywania wybranych kryzysów UE,

- implikacje nowej roli międzynarodowej Niemiec dla współpracy z Rosją i Polską.

Podjęty temat stanowi fragment szerszych badań autora na temat poszukiwania nowej roli i odpowiedzialności międzynarodowej Niemiec w dobie globalizacji i kryzysów oraz ich implikacji dla współpracy polsko-niemieckiej ${ }^{1}$. Ograniczone ramy artykułu pozwalają autorowi jedynie na syntetyczne sformułowanie własnych tez i hipotez badawczych w oparciu o źródła, literaturę przedmiotu oraz własną bieżącą obserwację uczestniczącą wydarzeń za pomocą mediów, zwłaszcza zaś niemiecko-francuskiego kanału dokumentacyjnego TV-Phoenix, które znajdą wybiórcze odzwierciedlenie w bibliografii.
\end{abstract}

\section{Istota ksztaltowania koncepcji nowej roli i odpowiedzialności międzynarodowej Niemiec}

Generalnie można przyjąć, iż rola i pozycja międzynarodowa państwa jest określana przez jego wyznaczniki wewnętrzne i zewnętrzne, zarówno obiektywne, jak też subiektywne (Zięba, 2004). W ciagu niespełna 20 lat po zjednoczeniu ogromnym wy-

${ }^{1}$ E. Cziomer, Wyzwania nowej roli i odpowiedzialności międzynarodowej Niemiec $w$ dobie globalizacji oraz kryzysów gospodarczych i finansowo-politycznych UE po 2007 roku. Projekt indywidualny $\mathrm{nr}$ 00285/2015/KJ, realizowany w latach 2015-2017 w ramach porozumienia Krakowskiej Akademii im. Andrzeja Frycza Modrzewskiego w Krakowie z Fundacją Współpracy Polsko-Niemieckiej w Warszawie. Dodatkowo pod redakcją naukową autora przygotowano w ramach powyższego projektu w 2016 r. pracę zbiorową w ramach „Krakowskich Studiów Międzynarodowych” $\mathrm{z}$ udziałem autorów polskich, niemieckich i ukraińskich pt. Znaczenie nowej roli międzynarodowej Niemiec dla wspótpracy polsko-niemieckiej $w$ drugiej dekadzie XXI wieku. Praca powyższa składa się z dwóch tomów: Polska i Niemcy w Unii Europejskiej (1) oraz Wyzwania wspótpracy polsko-niemieckiej oraz polityki wschodniej Unii Europejskiej (2) (w druku). 
siłkiem finansowym (ok. 2 bilionów euro kosztów jedności niemieckiej) kolejnym ekipom rządzącym w Bonn/Berlinie (od 1999/2000) udało się doprowadzić do scalenia obu części Niemiec (Bohr, Krause, 2011, s. 63-90). W kontekście tych przemian można przyjąć, iż obiektywnymi wyznacznikami silnej pozycji międzynarodowej zjednoczonych Niemiec w drugiej dekadzie XXI w. stały się między innymi takie czynniki jak: korzystne położenie geopolityczne w centrum Europy, znaczący potencjał demograficzny i gospodarczy, wysoki poziom dobrobytu ludności, rozwoju technologicznego oraz infrastruktury, znaczna stabilność wewnątrzpolityczna, jak również ich rozbudowane interesy i powiązania globalne (Cziomer, 2010, s. 19-47). Dzięki powyższym atutom Niemcy są zarówno długoletnim członkiem NATO i UE, jak też zasiadają we wszystkich ważniejszych organizacjach międzynarodowych o charakterze politycznym, gospodarczym i społecznym, w tym między innymi w ugrupowaniach najbogatszych krajów świata - G-7/8 i G-20 oraz licznych wyspecjalizowanych agendach ONZ. W sumie więc można w tym miejscu stwierdzić, iż Niemcy od początku drugiej dekady XXI w. stały ważnym mocarstwem europejskim, głównie geoekonomicznym, posiadającym dodatkowo rozbudowane interesy, aspiracje oraz powiązania ekonomiczno-polityczne w skali globalnej.

USA już bezpośrednio po zjednoczeniu w 1991 r. zaproponowały Niemcom ,,partnerstwo w przywództwie" (partneship in Leadership) na arenie międzynarodowej, oczekując od długoletniego chadeckiego kanclerza Helmuta Kohla (1982-1998) między innymi militarnego zaangażowania się rządu federalnego w wojnie w Zatoce Perskiej przeciwko reżymowi wojskowemu w Iraku. Wobec protestów, masowych demonstracji oraz istnienia w dawnej RFN wielu zwolenników ruchów pokojowych i tzw. kultury wstrzemięźliwości militarnej - rząd federalny zdecydował się nie wysyłać oddziałów Bundeswehry do Iraku, ale w formie pewnego rodzaju rekompensaty tzw. dyplomacji czekowej - przekazano koalicji antyirackiej na czele z USA pomoc finansową i materialną w wysokości ok. 18 mld DEM. Sytuacja uległa stopniowej zmianie dopiero w wyniku orzeczenia Federalnego Trybunału Konstytucyjnego z 5 lipca 1995 r., zezwalającego rządowi federalnemu na wysyłanie zagranicznych misji wojskowych, ale za każdorazową zgodą Bundestagu. Jednak jeszcze w XXI w. sprawa udziału Bundeswehry w zagranicznych misjach wojskowych wzbudza często wiele kontrowersji politycznych (por. szerzej Malinowski, 2009, s. 46 i n.).

Po burzliwych rządach koalicji socjaldemokratyczno-zielonej SPD/Sojusz 90/Zieloni na czele z kanclerzem Gerhardem Schroederem (1998-2005) od drugiej połowy pierwszej dekady XXI w. następowały stopniowa stabilizacja wewnętrzna oraz wyraźne umocnienienie pozycji międzynarodowej Niemiec. Proces powyższy można ująć syntetycznie następująco:

- W okresie do 2005 r. Niemcy stały się w pewnym sensie ,,chorym człowiekiem Europy" z recesją i masowym bezrobociem (ponad $5 \mathrm{mln}$ osób). Doprowadziło to do przedterminowych wyborów do Bundestagu, które nieznacznie wygrała CDU/CSU na czele z Angelą Merkel jako przewodniczącą CDU oraz nową kanclerz. Historyczną zasługą kanclerza Schroedera z SPD było przeforsowanie w 2003 r. w Bundestagu wbrew krytyce oraz licznym oporom wewnętrznym największej reformy w historii polityki socjalnej i zabezpieczenia społecznego w Niemczech - „Agendy 2010”. Zakładała ona zaostrzenie kryteriów przyznawania pomocy społecznej, do- 
puszczając zarazem różne elastyczne formy zatrudnienia celem ograniczenia bezrobocia. Reforma powyższa przyniosła wymierne efekty dopiero pod koniec pierwszej dekady XXI w., przyczyniając się średniofalowo nie tylko do poprawy wewnętrznej sytuacji społeczno-gospodarczej i finansowej, lecz również wzmocnienia roli i pozycji międzynarodowej Niemiec. Równocześnie warto jednak w tym miejscu podkreślić, iż wprowadzenie przez kanclerza i przewodniczącego Schroedera „Agendy 2010" pozbawiło jego partię masową SPD w kolejnych wyborach do Bundestagu poparcia ze strony znacznej części dotychczasowego elektoratu wśród grup najuboższych oraz części klasy średniej ze względu na pogorszenie się ich sytuacji materialnej. Odzwierciedlały to kolejne wyniki wyborów do Bundestagu SPD w latach 2002-2013 (2002-40,9\%, $2005-34,2 \%, 2009-23 \%, 2013-26,6 \%)$. W ten sposób po 2005 r. SPD została poważnie osłabiona w stosunku do CDU/CSU, która w latach 2005-2016 jako główna siła rządząca osiagała w wyborach do Bundestagu stopniowo o wiele lepsze wyniki ( $2005-35,2 \%, 2009-33,8 \%$ oraz $2013-41 \%)$. W latach 2005-2016 bez przerwy szefem rządu federalnego pozostawała kanclerz Angela Merkel. W różnych konstelacjach politycznych przewodniczyła ona kolejnym rządom Wielkiej Koalicji CDU/CSU i SPD (2005-2009), koalicji chadeckoliberalnej CDU/CSU/FDP (2009-2013) oraz od 2013 r. ponownie CDU/CSU i SPD (kadencja kończy się we wrześniu 2017 r.). Merkel jako przewodnicząca największej partii chadeckiej Niemiec - CDU od 2000 r. jest zatem aktualnie politykiem najdłużej sprawującym funkcję szefa rządu demokratycznego w Europie oraz całym świecie zachodnim. W ramach niemieckiego systemu politycznego i porządku prawnego jako kanclerz federalny posiada ona duże uprawnienia w zakresie wytyczania, realizacji i kontroli polityki wewnętrznej, zagranicznej i bezpieczeństwa RFN (Cziomer, 2010, s. 24-75; Chronik Deutschland, 2014, s. 409-456).

- Pierwszym poważnym wyzwaniem dla rządu Wielkiej Koalicji CDU/CSU/SPD na czele z kanclerz Merkel - obok przygotowania wstępnych założeń Traktatu Lizbońskiego UE w pierwszym półroczu 2007 r. był wybuch światowego kryzysu finansowego, który ujawnił się już jesienią 2007 r. ze względu na brak prawidłowego nadzoru bankowego w powiązaniu z masowymi spekulacjami w budownictwie mieszkaniowym oraz przepływem funduszy inwestycyjnych, upadłości banków itp. Kryzys szybko przemieścił się w 2008 r. z USA do najbogatszych krajów świata zachodniego, w tym Niemiec, przybierając nazwę - światowego kryzysu finansowo-gospodarczego 2007+. Łączna wartość strat z tytułu powyższego kryzysu na początku drugiej dekady XXI w. dla całej gospodarki świata zachodniego obliczano na ok. 4,1 bilionów dolarów amerykańskich (USD). W RFN same straty prywatnego sektora bankowego wyniosły ponad 140 mld euro. Pierwsze działania osłonowe rządu federalnego zmierzały do ratowania banków. Na początku października $2008 \mathrm{r}$. kanclerz Merkel wspólnie z ministrem finansów Peerem Steinbrueckiem z SPD na wspólnej konferencji prasowej zapowiedzieli bez posiadania zabezpieczeń finansowych udzielenie pełnych gwarancji kredytowych dla oszczędności wszystkich prywatnych wkładów w bankach niemieckich. Była to ważna decyzja psychologicznopolityczna dla uspokojenia pierwszych oznak paniki w społeczeństwie niemieckim. Punkt kulminacyjny kryzysu nastapił w 2009 r. kiedy bankrutowały masowo małe i średnie przedsiębiorstwa, a spadek realnego PKB osiąnął poziom $-6,0 \%$, dopro- 
wadzając między innymi do recesji w RFN. Dla załagodzenia negatywnych skutków gospodarczo-społecznych rząd federalny musiał wyasygnować w 2008 r. na dwa ratunkowe pakiety koniunkturalne o łącznej wartości ok. 740 mld euro w formie różnych świadczeń społecznych, w tym dopłat do zarobków celem utrzymania produkcji i miejsc pracy w zakładach oraz wielu innych dotacji, zwłaszcza zaś na udzielanie gwarancji kredytowych firmom i bankom. Do stopniowego przezwyciężenia powyższego kryzysu doszło dopiero w 2010 r. Było to możliwe między innymi dlatego, iż Niemcy jako piąta gospodarka świata znacznie rozbudowały od połowy pierwszej dekady XXI wieku swoje kontakty gospodarczo-handlowe z krajami wschodzących gospodarek, w tym zwłaszcza z krajami grupy BRICS (Brazylia, CHRL, Indie, Rosja i Afryka Południowa), które nie były dotknięte skutkami kryzysu finansowo-gospodarczego 2007+. Kraje grupy BRICS odgrywały dodatkowo coraz ważniejszą rolę w działalności 20 najważniejszych gospodarek świata. Decyzja powyższa miała nie tylko znaczenie gospodarczo-handlowe, lecz także długofalowy wymiar strategiczno-polityczny dla kształtowania nowej roli i odpowiedzialności międzynarodowej Niemiec. Niemcy zaczęły ogrywać także większą rolę koordynacyjną w ramach G-20. Nie uchroniło to jednak Niemiec przed krytyką w ramach G-20 z tytułu uzyskiwania nadmiernych i systematycznych, rocznych nadwyżek eksportowych w handlu zagranicznym (Illing, 2012, s. 13-76).

- W momencie utworzenia wspomnianego już wyżej rządu koalicji chadecko-liberalnej (CDU/CSU/FDP) jesienią 2009 r. wszedł w życie Traktat Lizboński UE, który wzmacniał pozycję kanclerz Merkel kosztem koalicjanta - ministra spraw zagranicznych Guido Westerwelle'go jako wicekanclerza i przewodniczącego FDP. Od tej pory Merkel jeździła samodzielnie na szczyty UE do Brukseli, a wszystkie kluczowe decyzje w polityce europejskiej i międzynarodowej RFN zapadały w Urzędzie Kanclerskim, marginalizując resort spraw zagranicznych - Urząd Spraw Zagranicznych (AA) Nowy rząd postanowił wykorzystać niemiecki potencjał naukowo-badawczy i ekspercki, koordynowany przez dwa czołowe think thanki w Berlinie - Fundację Nauka i Polityka (SWP) oraz Niemieckie Towarzystwo Polityki Zagranicznej (DGAP) do wypracowania wspólnie ze Sztabem Planowania AA zmodyfikowanych koncepcji polityki zagranicznej i bezpieczeństwa Niemiec. Można do nich zaliczyć przede wszystkim: 1) obszerny dokument: Globalizacje kształtować - partnerstwo rozbudować - odpowiedzialność dzielić, którego rangę podniesiono poprzez specjalną uchwałę Bundestagu do oficjalnej koncepcji rządu federalnego. Dokument powyższy przedstawiał priorytety całokształtu polityki zagranicznej i bezpieczeństwa Niemiec, uwzględniając jednak w szerszym zakresie ich relacje w odniesieniu do „współdecydujących mocarstw” (Gestaltungsmaechte) na trzech kontynentach - Ameryce Łacińskiej, Azji i Afryce. Jego najważniejsze punkty ciężkości przedstawiały się następująco: 1) „Europa i jej sąsiedzi” z priorytetami rozwiązania kryzysu strefy euro oraz wzmocnienia WPZBiO UE; 2) ,współpraca transatlantycka" z ważnymi elementami działania w ramach NATO oraz ścisłą współpracą z USA celem utworzenia wspólnego Rynku Wewnętrznego po zakończeniu zainicjowanych rozmów UE-USA (TIPP); 3) dalsze angażowanie się Niemiec we współpracę w ramach ONZ, G-8 i G-20 oraz rozwiązywanie problemów globalnych w aspekcie dwu- i wielostronnym; 4) współpraca z ,nowymi centrami 
siły" (neue Kraftzentren), czyli zacieśnienie stosunków z krajami wschodzących gospodarek jak Chiny, Indie, Brazylia i Rosja, Afryka Południowa (BRICS) oraz innymi krajami Azji, Afryki i Ameryki Łacińskiej, z którymi współpraca rozwija się we wszystkich płaszczyznach i dobrze służy interesom politycznym i gospodarczym Niemiec; 5) dążenie do: a) wzmocnienia ochrony praw człowieka oraz b) udzielania pomocy humanitarnej w skali globalnej i regionalnej (Gestaltungskonzept der Bundesregierung, 2012).

- W uzupełnieniu do powyższej koncepcji dwaj eksperci SWP w Berlinie - Markus Kaim i Volker Perthes rekomendowali rządowi strategię długofalowego dochodzenia przez Niemcy do umocnienia swojego przywództwa międzynarodowego do 2030 r. poprzez podjęcie następujących działań:

a) wypracować zdolność i gotowość elit politycznych i kół rządzących Niemiec do przewodzenia w polityce międzynarodowej,

b) opanować umiejętność przejęcia „,roli mocarstwa współ-przewodzącego” (MitFuehrungsmacht) w Europie i najbliższym sąsiedztwie,

c) zachować elastyczne podejście do zmieniających się konstelacji układu sił w świecie,

d) wykorzystać własne wartości do tworzenia spójnej koncepcji ładu międzynarodowego w polityce zagranicznej i bezpieczeństwa Niemiec,

e) opanować zdolności dokonywania wyboru prawidłowych partnerów do współdziałania w warunkach szybko zmieniających się wyznaczników oraz nowych ram międzynarodowych (Kaim, Perthes, 2012).

- Pod koniec kadencji koalicji chadecko-liberalnej Sztab Planowania AA zlecił wykonanie kolejnej, bardziej kompleksowej i pogłębionej ekspertyzy w formie raportu końcowego z badań na temat nowej roli i odpowiedzialności międzynarodowej Niemiec pt. Nowa siła. Nowa odpowiedzialność. Elementy niemieckiej polityki zagranicznej i bezpieczeństwa dla świata w okresie przełomu (Neue Macht, neue Verantwortung, 2013). Prace nad raportem trwały od listopada 2012 r. do października 2013 z udziałem kilkudziesięciu specjalistów i ekspertów z różnych dyscyplin, przedstawicieli kół gospodarczych oraz polityków Bundestagu oraz rządu federalnego różnych opcji pod organizacyjnym i merytorycznym kierownictwem Niemieckiego Instytutu Bezpieczeństwa i Polityki, działającego w ramach wspomnianego już wyżej czołowego think thanku w Berlinie SWP oraz amerykańskiej fundacji transatlantyckiej w Niemczech (German Marshall Fund of the United States - GMF). Raport powyższy miał poza walorami merytorycznymi również znaczenie praktyczne, zawierając wiele konkretnych rekomendacji dla rządu federalnego w odniesieniu do całokształtu polityki zagranicznej i bezpieczeństwa Niemiec. Postulował też przejęcie przez Niemcy większej odpowiedzialności oraz przywództwa międzynarodowego, zwłaszcza zaś w odniesieniu do UE. Do treści raportu nawiązywała między innymi bezpośrednio umowa nowego rządu Wielkiej Koalicji CDU/CSU i SPD, utworzonego po wyborach do Bundestagu 27 września 2013 r. Dotyczyło to między innymi sformułowania rozdziału 7 umowy koalicyjnej z 27 listopada 2013 r. pt. Odpowiedzialność w świecie, w którym stwierdzono między innymi: ,[...] Niemcy są gotowe do przejęcia swojej roli międzynarodowej. Chcemy aktywnie współkształtować porządek globalny. Będziemy się przy tym kierowali 
interesami i wartościami naszego kraju. W skali całego świata Niemcy opowiadają się za pokojem, wolnością i bezpieczeństwem oraz sprawiedliwym porządkiem międzynarodowym, przestrzeganiem praw człowieka, stosowaniem prawa międzynarodowego, jak również zrównoważonego rozwoju i zwalczania biedy. Jesteśmy gotowi stosownie do oczekiwań uczestniczyć w rozwiązywaniu kryzysów i konfliktów. Na pierwszym miejscu stawiamy środki dyplomatyczne, regulacje pokojowe i współpracę rozwojową. Opowiadamy się za wiarygodnością oraz solidarnością sojuszniczą. Zamierzamy być dobrym partnerem przy kształtowaniu sprawiedliwego ładu pokojowego" (Deutschlands Zukunft gestalten, 2013, s. 165).

Ogólnie można stwierdzić, iż zarówno raport SWP/GMF z października, jak też postanowienia umowy koalicyjnej nowego rządu CDU/CSU i SPD z końca listopada 2013 r. stanowiły w aspekcie programowym zasadniczy trzon nowej strategii zewnątrzpolitycznej Niemiec, wyrażającej gotowość do przejęcia większej odpowiedzialności i przywództwa w stosunkach międzynarodowych. Zawarte w nich interesy, zasady, cele i wartości znalazły następnie wyraz w deklaracjach rządowych kanclerz Merkel oraz szeregu innych dokumentach i wypowiedziach oficjalnych czołowych polityków niemieckich.

Nieprzypadkowo sprawa powyższa została nagłośniona na cieszącej się dużą renomą międzynarodową na przełomie stycznia i lutego 2014 r. w Monachium - jubileuszowej 50-tej Monachijskiej Międzynarodowej Konferencji Bezpieczeństwa (MSK) z udziałem czołowych polityków i ekspertów z Niemiec, USA, wszystkich ważniejszych krajów europejskich oraz z innych kontynentów. W dniu 31 stycznia 2014 r. z ważnym przemówieniem wystapił prezydent federalny Joachim Gauck, opowiadając się zdecydowanie za koniecznością zwiększenia aktywności międzynarodowej i przywództwa Niemiec, nie wykluczając interwencji wojskowych Bundeswehry przy rozwiązywaniu konfliktów zbrojnych oraz przywracaniu stabilności zagrożonych regionów i państw (Gauck, 2014, s. 1-9). W drugim dniu obrad MSK 1 lutego 2014 r. ministrowie spraw zagranicznych - Frank Walter Steinmeier (Steinmeier, 2014) oraz obrony Ursula von der Leyen (Leyen, 2014) w wystapieniach pogłębili tezy prezydenta Gaucka w odniesieniu do potrzeby kreowania nowego podejścia do polityki zagranicznej oraz bezpieczeństwa i obrony Niemiec.

W ocenie niektórych ekspertów niemieckich wystąpienia w Monachium prezydenta Gaucka oraz ministrów Steinmeiera i von der Leyen miały wprawdzie aspekt propagandowy, ale zarówno w kręgach politycznych i eksperckich, jak też w przekazach medialnych, podkreślały determinację nowego rządu CDU/CSU/SPD w aktywizacji nowej polityki zagranicznej i bezpieczeństwa. Efektem powyższych wystapień było zainicjowanie przez Steinmeiera w ramach szerokiego programu badawczego Przeglad 2014: w polityce zagranicznej myśleć dalekosiężnie. Kryzys - Europa - Porzq̨ek, w którym 57 ekspertów, naukowców oraz publicystów z 26 państw zgłosiło swoje oceny i uwagi pod adresem polityki zagranicznej Niemiec (zob. Review 2014). Po przeanalizowaniu zawartych w nich rekomendacji poszczególne komórki AA decydowały dopiero o praktycznej możliwości ich zastosowania (zob. Rinke, 2014). Na marginesie warto dodać, iż równolegle do prac nad Review 2014 interdyscyplinarny zespół z udziałem ponad 20 naukowców oraz ekspertów niemieckich i zagranicznych postanowił w aspekcie teoretycznym i praktycznym dokonać odrębnej, miejscami bar- 
dzo krytycznej oceny, włączając się do powyższej debaty nad polityką zagraniczną i bezpieczeństwa Niemiec (zob. Hellmann, Jacobi, Urrestararazu, 2015).

W sumie więc wypracowane w latach 2012-2013/2014 koncepcje i założenia nowej roli i odpowiedzialności międzynarodowej Niemiec jako mocarstwa współkształtującego (Gestaltungsmacht) starano się stosownie do okoliczności oraz powstałych możliwości wykorzystywać do rozwiązywania konkretnych problemów, w tym również kumulujących się kryzysów UE (zob. Hellmann, 2016, s. 3-10).

\section{Ogólna ocena roli Niemiec w próbach rozwiązywania wybranych kryzysów UE}

Dzięki włączeniu się w proces integracji europejskiej dawna RFN uzyskała nie tylko suwerenność, dobrobyt i bezpieczeństwo w sojuszu zachodnim (1955), ale poprzez politykę odprężenia i przezwyciężenie konfliktu Wschód-Zachód - pokojowe zjednoczenie Niemiec (1990). W tym kontekście historycznym oraz współczesnym zaangażowanie się w reformy i poszerzenie UE stały się centralnym problemem polityki europejskiej wszystkich rządów niemieckich po 1990 r., ponieważ Niemcy stały się głównym beneficjentem procesu jednoczenia się Europy. Od przełomu pierwszej i drugiej dekady XXI w. wzrost roli Niemiec w UE wynikał z systematycznej poprawy koniunktury gospodarczej, wzrostu nadwyżek w handlu zagranicznym, spadku bezrobocia i innych korzystnych wskaźników gospodarczo-finansowych. Innymi słowy z ,chorego człowieka Europy” Niemcy przekształciły się w ,lokomotywę koniunktury gospodarczej w UE" (por. Frantzscher, 2014, s. 18-46). Jednak z drugiej strony od początku drugiej dekady XXI w. nasilały się zarówno w łonie samej UE, jak też w jej najbliższym otoczeniu, określone kryzysy i konflikty, stanowiące bądź to ogromne wyzwanie, bądź też zagrożenie dla jej dalszego funkcjonowania. Można do nich zaliczyć przede wszystkim takie kryzysy jak: strefy euro po 2009 r., rosyjsko-ukraiński od 2014 r., nielegalnej migracji do UE od drugiej połowy 2015 r. oraz wyjście Wielkiej Brytanii z UE (Brexit) po referendum z 22 czerwca 2016 r. Szczegółowa analiza powyższych kryzysów wykracza poza ramy artykułu. Ogólna oceny roli Niemiec obejmie tyko trzy pierwsze z wymienionych wyżej kryzysów (zob. szerzej Cziomer, 2016a, s. 21-47).

Kryzys strefy euro (aktualnie 19 państw UE) ujawnił się po ogłoszeniu przez Grecję pod koniec 2009 r. niemożności obsługi swojego zadłużenia zagranicznego, które w 2010 r. wynosiło 273,4 mld euro, wzrastając w 2011 r. do ok. 300 mld euro. Powyższy kryzys zadłużenia objął od 2010 r. dodatkowo w różnym stopniu Portugalię, Irlandię, Hiszpanię i Włochy (tzw. kraje grupy PIIGS), a w mniejszym stopniu Francję, choć jej sytuacja gospodarcza od kilku lat systematycznie się pogarsza. Nawet bez częściowego rozwiązania kryzysu zadłużenia Grecji nad strefą euro zawisłoby niebezpieczeństwo rozpadu, co miałoby niekorzystne następstwa nie tylko dla Niemiec, lecz również funkcjonowania całej UE i gospodarki światowej. Ratowanie Grecji było konieczne ze względu na następstwa niekorzystnych notowań międzynarodowych agencji ratingowych dla całej strefy euro oraz liczenie chociażby na odzyskanie części pożyczonych Grecji pieniędzy przez prywatne banki międzynarodowe, 
w tym również niemieckie - 33,9 mld euro i francuskie - 56,7 mld euro. Dodatkowo pożyczki oraz papiery wartościowe niemieckich podmiotów prywatnych, publicznych i państwowych na obszarze całej strefy euro UE opiewały łącznie w 2014 r. na sumę ok. 3,4 biliona euro. Po uzgodnieniach kanclerz Merkel z prezydentem Francji Nicolasem Sarkozy'm - 16 krajów strefy euro (bez Słowacji) oraz Międzynarodowy Fundusz Walutowy (MFW) udzieliły Grecji 6 maja 2010 r. doraźną gwarancję kredytową na pożyczkę w wysokości 110 mld euro na obsługę kredytów na zasadach komercyjnych (oprocentowanie 4,75\%), z czego na Niemcy stosownie do ich potencjału gospodarczo-finansowego w Eurogrupie przypadało - 27,92\%. Nie wchodząc w tym miejscu w kwestie szczegółowe należy podkreślić, iż niemiecka strategia Ogólnej stabilizacji Unii Gospodarczo-Walutowej - przygotowana na przełomie 2010/2011 r. zakładała udzielanie zadłużonym krajom PIIGS gwarancji przez specjalne utworzone tymczasowe instrumenty finansowe za cenę reform i wyrzeczeń budżetowo-finansowych zadłużonych krajów. Została ona zatwierdzono w ramach Traktatu o stabilizacji, koordynacji i zarzqdzaniu unia gospodarczq $i$ walutowa po jego podpisaniu 1 marca 2012 r. przez 25 państw członkowskich UE (bez Czech i Wielkiej Brytanii) wraz ze stałym Europejskim Funduszem Stabilizacyjnym (FSM) oraz z chwila jego ratyfikacji przez 12 państw Eurogrupy 1 stycznia 2013 r. Strategia Niemiec polegała generalnie na udzielaniu gwarancji kredytowych zadłużonym państwom w zamian za programy oszczędnościowe, kontrolowane przez przedstawicieli Komisji Europejskiej, EBC oraz MFW. Forsowana przez kanclerz Merkel i niemieckiego ministra finansów Wolfganga Schaueble w ramach działań Trojki rygorystycznego narzucania Grecji ostrych cięć budżetowych na cele społeczne pogarszało systematycznie jej sytuację społecznogospodarczą (Cziomer, 2014, s. 271-288).

Zasadniczym elementem działań Niemiec na rzecz stabilizacji strefy euro do połowy 2013 r. był ich wkład finansowy w pakiety ratunkowe dla zadłużonych krajów na okres trzech lat w ramach umów dwustronnych dla Grecji (pierwszy (I) 2010-2013 oraz drugi (II) 2012-2014), Irlandii (2010-2013), Portugalii (2011-2014), banków hiszpańskich (2013-2016) oraz Cypru (2013-2016). Dodatkowo Niemcy partycypowały procentowo w udziałach pomocy MFW, wykupie papierów dłużnych oraz zobowiązaniach targetowych EBC. Na 10 mld euro przyznanych Cyprowi Niemcy partycypowały w wysokości $29 \%$. Warto zaznaczyć, iż Niemcy odrzucały zdecydowanie ustanowienie tzw. eurobonów, czyli przejęcie wspólnej odpowiedzialności za całkowite zadłużenie wszystkich krajów Eurogrupy. Tolerowano natomiast aktywność EBC w krótkoterminowych zakupach długów poszczególnych państw Eurogrupy na zasadach komercyjnych, dopuszczając do emisji przez EBC waluty euro na rynki kapitałowe. Nie wchodząc w tym miejscu w szereg kwestii szczegółowych można stwierdzić, iż ze względu na swój wkład finansowy w pakiety ratunkowe oraz silną pozycję ekonomiczno-finansową - Niemcy odegrały pierwszoplanową rolę w dążeniu do przezwyciężenia kryzysu strefy euro w latach 2010-2013. Ze względu na pogarszającą się długofalowo sytuację gospodarczą w strefie euro, mimo pewnych zastrzeżeń, Francja popierała niemiecką strategię narzucania wszystkim krajom PIIGS, a zwłaszcza Grecji, znacznego oszczędzania. Udało się w ten sposób wprawdzie załagodzić sytuację poprzez bieżące interwencje zakupów przez EBC długów, doprowadzając tylko do częściowej stabilizacji krajów PIIGS (por. Cziomer, 2013, s. 61-116). 
Z ocen greckich wynika, iż strategia Merkel wobec Grecji przyniosła tylko doraźnie zażegnanie kryzysu bez widoku na jego ostateczne rozwiązanie. Osłabia to możliwość przejęcia w pełni akceptowanej w Grecji i całej UE roli przywódczej Niemiec (Katsiopulis, 2015, s. 251-275). Na początku 2015 r. wybory parlamentarne w Grecji wygrała populistyczna partia lewicowa Syriza na czele z Alexisem Tsiprasem, która odmówiła dalszych cięć wydatków społecznych, przeciwstawiając się wyraźnie przez 5 miesięcy na jakiekolwiek ustępstwa pod adresem Niemiec i pozostałych 18 krajów. Dopiero w lipcu 2015 r. pod groźbą trudnego do przeprowadzenia zgodnie z prawem europejskimi - Grexitu, czyli opuszczenia strefy euro - Grecja uzyskała 3 pakiet ratunkowy w wysokości 86 mld euro na lata 2015-2018. Decyzję w sprawie przyznania Grecji powyższego kredytu w kilku ratach na twardych warunkach przesądziła w RFN ostatecznie kanclerz Merkel, mimo wielu zastrzeżeń ze strony resortu finansów oraz Niemieckiego Banku Federalnego (Griechenland erhaelt neuen Miliardenkredit, 2015).

Na początku 2016 r. MFW, EBC i Komisja Europejska stanęły przed wyzwaniem udzielenia Grecji dalszego pakietu ratunkowego w wysokości ok. 86 mld euro dla utrzymania płynności budżetowej. Szczegółowe warunki przyznania pakietu nie zostały jeszcze dokładnie uzgodnione, ale posunięcie takie będzie prawdopodobnie nieuchronne ze względu na pierwszoplanową rolę Grecji w ciagu 2016 r. w powstrzymywaniu napływu nielegalnych uchodźców do UE, w tym zwłaszcza do Niemiec (Schulden und Flüchtlinge, 2016).

W sumie można stwierdzić, iż pomyślne zakończenie kontrowersji wokół warunków przyznania trzeciego pakietu ratunkowego dla Grecji w pierwszej połowie 2015 r. potwierdziło pierwszoplanową rolę Niemiec oraz osobiście kanclerz Merkel w próbach rozwiązywania kryzysu strefy euro. Jednak niemieckie gwarancje kredytowe nie przesądziły jednak ostatecznego przezwyciężenia kryzysu. Kryzys powyższy został jedynie przejściowo zażegnany, przysparzając $\mathrm{w}$ dodatku Niemcom znaczne korzyści finansowe. Według obliczeń Instytutu Badań Gospodarczych w Halle (IWH) z tytułu samego oprocentowania niemieckich pożyczek i różnych form gwarancji kredytowych dla Grecji w latach 2010-2015 Niemcy osiagnęły łącznie ok. 100 mld euro zysku (por. German's benefis, 2015), głównie poprzez bardzo korzystną sprzedaż swoich papierów dłużnych, zyski z odsetek kredytowych itp. Budzi to dodatkowe irytacje wśród państw PIIGS. Natomiast Grecja nie zrealizowała w znacznej części przyjętych w lecie 2015 r. zobowiązań przeprowadzenia zalecanych przez Instytucje (dawna Trojka) reform. Zapowiada to utrzymanie się sytuacji kryzysowej w Grecji, na którą nakładają się dodatkowo trudności z napływem nielegalnych migrantów.

Kryzys ukraińsko-rosyjski stanowi poważne wyzwanie i zagrożenie dla interesów politycznych i gospodarczych Niemiec zarówno jako członka NATO i UE, jak też deklarowanego po 2005 r. partnera strategicznego Rosji. Po nieudanych próbach mediacji rozwiązania konfliktu między prezydentem W. Janukowyczem i opozycją na Majdanie (21 lutego 2014 r.) przez szefów dyplomacji Niemiec wraz z Francją i Polską w Kijowie, aneksji Krymu 18 marca 2014 r. przez Rosję oraz poparciu Kremla dla separatystów w Donbasie od wiosny 2014 r. rząd CDU/CSU/SPD zastosował podwójną strategię wobec Rosji:

1) podtrzymywania gotowości do dialogu z Rosją przy założeniu, iż można ją będzie skłonić do bezpośrednich rozmów z Ukrainą w celu przywrócenia pokoju w Donbasie; 
2) gotowość wypracowania i wdrożenia sankcji UE i USA jako instrumentu nacisku na Rosję.

Od lata 2014 r. główny ciężar kontaktów z prezydentem rosyjskim W. Putinem w ramach tzw. formatu normandzkiego wzięła na siebie kanclerz Merkel wraz z prezydentem Francji F. Hollandem, wspomagani szefami dyplomacji obu państw. Równocześnie z pozostałymi państwami NATO i UE Niemcy ze względu na niepowodzenie opcji 1 przeszły do opcji 2, uczestnicząc w przygotowaniach kolejnych sankcji przeciwko Rosji od połowy 2014 r. do chwili obecnej (koniec 2016). Na przełomie 2014/2015 r. po wstępnych konsultacjach Merkel z Holladem, Putinem, prezydentem Ukrainy P. Poroszenko, przedstawicielem OBWE i separatystów doprowadzili 12 marca 2015 r. w Mińsku do podpisania rozejmu na zasadach zachowania integralności Donbasu z Ukrainą przy uwzględnieniu utrzymania samorządności dla obwodów - Donieck i Ługańsk, czyli w domyśle de facto wpływów przez prorosyjskich separatystów (por. szerzej Cziomer, 2015, s. 489-502). Praktyczna oraz ciagle deklarowana i oczekiwana realizacja postanowień rozejmu z Mińska napotyka na trudności akceptacji w Radzie Najwyższej Ukrainy i dlatego trudno w obecnej sytuacji formułować realistyczne perspektywy szybkiego rozwiązanie kryzysu ukraińsko-rosyjskiego. Można ogólnie przyjąć, iż Kreml mimo ujemnych następstw sankcji zachodnich i częściowej izolacji międzynarodowej będzie dążył do „zamrożenia” konfliktu w Donbasie oraz wykorzystania go do destabilizacji sytuacji na Ukrainie. Sprawa sprzecznej z prawem międzynarodowym aneksji Krymu przez Rosję pozostaje ciągle formalnie otwarta, ale w praktycznych działaniach dyplomatycznych schodzi na dalszy plan. Odrębnym zagadnieniem są percepcja wewnętrzna i kontrowersje wokół kryzysu ukraińskiego w Niemczech. W łonie niemieckiej elity intelektualnej nie ma zgodności w ocenie kryzysu rosyjsko-ukraińskiego. Jej część z różnych obozów politycznych sympatyzuje z interesami i stanowiskiem Rosji wobec Zachodu i Ukrainy (tzw. rozumiejący Putina - Putin-Versteher), a druga część stoi po przeciwnej stronie i ostro zwalcza politykę Putina. W łonie obozu rządzącego - znaczna większość polityków CDU na czele z Merkel zaostrza krytykę Kremla i opowiada się za utrzymaniem sankcji wobec Rosji. Natomiast SPD wraz z kołami handlowo-przemysłowymi, zwłaszcza skupionymi wokół Komisji Wschodniej Gospodarki Niemieckiej, występują przeciwko sankcjom oraz opowiadają się za wznowieniem współpracy z Rosją. Zbliżające się wybory do Bundestagu we wrześniu 2017 r. będą również sprzyjały dyskusjom i kontrowersjom wokół charakteru dalszej współpracy niemiecko-rosyjskiej. Równocześnie nie można przeoczyć znacznej roli Niemiec przy udzielaniu pomocy finansowej i gospodarczej Ukrainie oraz wspieraniu jej zabiegów o podpisanie umowy stowarzyszeniowej z UE w latach 2014-2016 (Cziomer, 2015, s. 39-56).

Kryzys nielegalnej migracji do UE. Według oficjalnych danych ONZ (UNHCR) na początku 2015 r. w skali całego świata było ok. 60 milionów migrantów, z czego tylko ok. $20 \mathrm{mln}$ to ,migranci międzynarodowi”, czyli osoby szukające schronienia poza granicami kraju zamieszkania. Spora część z nich, zamieszkała w Afryce Środkowej i Północnej oraz na Bliskim i Środkowym Wschodzie, ze względu na niekończące się wojny i konflikty zbrojne, nędzę, głód oraz brak perspektyw na przyszłość, działalność zorganizowanych grup przemytniczych itp., kierowała się nielegalnie głównie trasami przez Morze Śródziemne i Libię do Włoch, a w mniejszym stopniu do Hisz- 
panii, bądź też przez Turcję, Grecję, Bałkany Austrię do Niemiec i krajów północnych UE. Szczególnie wojny domowe w Afryce, jak też ich dalsza eskalacja w związku z powstaniem Państwa Islamskiego w Syrii i Iraku zwiększyły napływ nielegalnych migrantów (uchodźców) do UE: 2014 r. - ok. 714 000, 2015 - ok. 1,5 mln, z czego ok. $1,1 \mathrm{mln}$ do Niemiec. Poprzez podyktowaną względami humanitarnymi, ale nieprzemyślaną i pochopną politycznie decyzję szefów rządów Niemiec i Austrii (A. Merkel i W. Feymann) o całkowitym otwarciu granicy niemiecko-austriackiej i zawieszenia dla uchodźców klauzuli azylowej UE Dublin III od 5 września do 10 listopada 2015 r. doszło do niekontrolowanego napływu uchodźców głównie do Niemiec, gdzie istniały sieci migracyjne $\mathrm{z}$ wielu krajów świata $\mathrm{w}$ kilku pokoleniach, a $16,5 \% \mathrm{z}$ ponad 80 mln mieszkańców RFN posiada rodowód migracyjny. Mimo początkowego życzliwego przyjęcia uchodźców w Niemczech - trudności rejestracyjne i organizacyjne, obawy mieszkańców oraz ataki na ośrodki ich zakwaterowania ze strony sił prawicowo-nacjonalistycznych, ogromne koszta finansowe itp. doprowadziły do licznych wewnętrznych kontrowersji politycznych. Od początku 2016 r. spadała popularność partii rządzących i kanclerz Merkel, a coraz większe poparcie polityczne uzyskiwały ruchy narodowo-populistyczne na czele z Alternatywą dla Niemiec (AFD) (por. szerzej Cziomer, 2016b, s. 24).

W październiku 2015 r. kanclerz Merkel zakładała jeszcze możliwość rozwiązania kryzysu migracyjnego przy pomocy krajów członkowskich UE poprzez ich dyslokację. Przychylna planom Merkel Komisja Europejska przeforsowała na Radzie UE 24 października 2015 r. zwykłą większością głosów dyrektywę odnośnie ustalenia wiążących kwot obowiązkowego rozdzielnika przydziału 160000 nielegalnych uchodźców na 26 krajów członkowskich UE (bez Wielkiej Brytanii i Danii). Wywołało to ostry sprzeciw i odmowę ze strony krajów Grupy Wyszehradzkiej (Czech, Słowacji i Węgier). Polska - rząd PO/PSL - wyraziła zgodę na przyjęcie powyższej dyrektywy określonej grupy uchodźców, ale nowy rząd PIS od jesieni 2015 r. solidaryzował się z krajami Grupy Wyszehradzkiej i nie przyjmował w następnych miesiącach uchodźców. Tak samo postapiła zresztą większość państw członkowskich UE, co było nie tylko odcięciem się od niekonsultowanych zasad nowej polityki imigracyjnej Niemiec, ale stanowiło również wyraz podważania ich aspiracji do przewodzenia w UE. Zresztą zdecydowana większość uchodźców preferowała wyłącznie RFN jako kraj docelowy. W sumie więc w zimie 2015/2016 r. tylko niektóre kraje członkowskie przyjęły łącznie ok. 700 uchodźców z kontyngentu 160000 planowanych do dyslokacji przez Komisję Europejska. Największym zawodem dla Merkel było zaangażowanie się zaprzyjaźnionej Austrii w kierunku zamknięcia szlaku bałkańskiego ze względów wewnątrzpolitycznych na mocy porozumienia 24 lutego 2016 r. w Wiedniu z niektórymi krajami UE (Austria, Słowenia i Chorwacja) oraz Zachodnich Bałkanów (Albania, Bośnia i Hercegowina, Czarnogóra, Kosowo, Macedonia i Serbia). Niemcy i Grecja, które były temu przeciwne, w ogólne nie zostały zaproszone do Wiednia. Bułgaria była tylko obserwatorem. Decyzja powyższa zahamowała wprawdzie napływ nielegalnych uchodźców do Austrii i Niemiec, ale nie rozwiązywała problemu kumulacji napływających bez przerwy masowo uchodźców z Turcji do Grecji.

Merkel zdecydowała się na przełomie lutego/marca 2016 r. na przyspieszenie dyskutowanych już pod koniec 2015 r. rozwiązań w uzgodnieniu z wszystkimi krajami 
członkowskimi. Jej strategia postulowała więc połączenie przyjmowania uchodźców $\mathrm{w}$ powiązaniu z ochroną granic zewnętrznych UE, zwalczania grup przemytników oraz zwiększenie liczby centrów przyjmowania i rejestracji uchodźców w Grecji i Włoszech, jak również udzielenia pomocy w utrzymywaniu uchodźców niektórym krajom Bliskiego Wschodu i Afryki. W ten sposób powinno dojść do zahamowania ich masowej i nielegalnej migracji do UE oraz przekształcenia jej w przyszłości w legalny napływ migrantów. Nie wchodząc w tym miejscu w kwestie szczegółowe, należy wskazać tylko na najważniejsze porozumienia w tym zakresie, w których przygotowaniu w ramach UE aktywną rolę odegrały Niemcy:

- Utworzenie na szczycie UE-Afryka 11-12 listopada 2015 r. europejskiego Fundusz Powierniczego na rzecz stabilizacji i przeciwdziałania nielegalnej migracji ludności $w$ Afryce. Ma on być zasilony docelowo przez Komisję Europejską i kraje członkowskie w wysokości 2,8 mld euro. Realizacja będzie zależała w dużym stopniu od ustabilizowania się sytuacji w objętej wojną domową Libii.

- Niemcy przywiązywały szczególną wagę do szczytu UE-Turcja 29 listopada 2015 r. w Brukseli, który miał po wstępnych konsultacjach uzgodnić zasady ograniczenia migracji uchodźców przez Grecję do UE. Za przyjęcie takiego zobowiązania Turcji obiecano z jednej strony przyspieszenie rozmów akcesyjnych z UE, a z drugiej dodatkowo uzyskanie rekompensaty w wysokości 3 mld euro na zmniejszenie kosztów utrzymania ponad 2,7 mln uchodźców syryjskich w jej granicach. Równocześnie kraje UE zadeklarowały dodatkowo znaczenie odciążenie Turcji przejęciem odpowiedniego kontyngentu uchodźców syryjskich, którego wysokość wyniesie ok. 400000 uchodźców syryjskich w ciągu kilku lat. W uzupełnieniu do powyższych wstępnych uzgodnień na kolejnym szczycie UE-Turcja w Brukseli 18 marca 2016 r. doprecyzowano dodatkowo następujące kwestie:

- współpracę Turcji i Grecji z okrętami NATO patrolującymi Morze Egejskie w celu uszczelnienia granicy z Grecja;

- doprecyzowanie ostatecznie zasady przejmowania oczekujących w Grecji uchodźców na powrót do Turcji w liczbie ok. 400 000, za których UE przyjmie w stosunku 1:1 ok. 72000 uchodźców syryjskich i rozdzieli je na kraje członkowskie;

- z tytułu powyższej umowy Turcja dostanie dodatkowo $3 \mathrm{mld}$, czyli łącznie 6 mld euro do 2018 r. na utrzymanie uchodźców syryjskich na swoim terytorium;

- poza uzgodnionym już wcześniej przyspieszeniem rozmów akcesyjnych obywatele tureccy winni skorzystać już od lipca 2016 r. z przywileju ruchu bezwizowego do krajów UE.

- Niemcy odegrały również ważną rolę na konferencji w Londynie na początku lutego 2016 r. z udziałem 70 krajów dawców pomocy dla ludności syryjskiej objętej wojną odmową od $2011 \mathrm{r}$. W sumie zebrano 11 mld USD, z czego rząd RFN przekazał pomoc w wysokości 2,3 mld euro.

- Utworzenie przez UE na terenie Grecji i Włoch 11 centrów przyjęć i rejestracji dla migrantów (tzw. Hot Spotów), które byłyby w stanie nie tylko rejestrować, lecz także decydować o pozostaniu lub readmisji z UE wszystkich potencjalnych azylantów (EU-Gipfel zur Fluechtlingsfrage, 2016). 
Reasumując można ogólnie stwierdzić, iż problem nielegalnej migracji do UE i Niemiec jest daleki od rozwiązania. Po zamknięciu szlaku bałkańskiego z nastaniem wiosny 2016 r. uchodźcy znowu preferują szlak śródziemnomorski jako główny cel migracji do UE przez Włochy. Tylko w pierwszej połowie 2016 r. do Niemiec przybyło z różnych tras migracyjnych 220000 uchodźców. Interdyscyplinarny zespół badawczy SAT z Freiburga przedstawił następujące scenariusze hipotetycznego napływu uchodźców do UE w latach 2016-2017:

A. obowiązuje układ UE-Turcja z 18 marca 2016 r. bez zakończenia wojny domowej w Syrii, ale liczba uchodźców napływających do UE waha się od 1,3 do 2,1 mln (2016);

B. dochodzi do pokoju w Syrii, liczba uchodźców nie przekracza 1,8 mln;

C. zaostrza się wojna domowa w Syrii, liczba uchodźców zwiększa się do 2,3 mln;

D. ujawniają się nowe konflikty w Afryce na szeroką skalę (Nigeria, Egipt i inne do końca 2016) - do UE napływa ok. 3,7 mln uchodźców;

E. otwarte granice, w tym szlak bałkański - liczba uchodźców może się nawet hipotetycznie zwiększyć do 6,4 mln (Fluechtingsszenarien, 2016).

Reasumując można założyć hipotetycznie, iż najbardziej realistyczne wydaje się wystąpienie scenariuszy w nieco zmodyfikowanym wariancie A (w którym nie można do końca przewidzieć precyzyjnie dokładnej liczby uchodźców), który wymagałby jednak utrzymania porozumienia UE-Turcja z 18 marca 2016 r. oraz większego współdziałania wszystkich państw członkowskich UE w rozwiązywaniu złożonych problemów masowej migracji do UE.

\section{Implikacje wzrostu roli międzynarodowej Niemiec dla współpracy z Rosją i Polską}

Postępujący od początku drugiej dekady XXI w. stopniowy wzrost roli międzynarodowej Niemiec wiązał się z koniecznością zaangażowania się kolejnych rządów RFN w próby rozwiązywania zasygnalizowanych powyżej dwóch kryzysów UE. Nie pozostało to jednak bez implikacji dla ich współpracy z Rosja i Polska, które z kolei w różnym stopniu były dotknięte następstwami powyższych kryzysów UE.

Rosja jako partner strategiczny Niemiec i UE była tylko częściowo uwikłana w kryzys strefy euro, głównie ze względu na silne powiązania jej finansów i banków z Republiką Cypru, współpracującej z kolei z bankami greckimi. W bankach cypryjskich oligarchowie rosyjscy ulokowali w formie depozytów ok. 26 mld USD, które w 2013 r. zostały częściowo zamrożone i opodatkowane dla potrzeb stabilizacji waluty cypryjskiej (por. szerzej Cziomer, 2013, s. 88). Sprawa powyższa, forsowana głównie przez niemieckiego ministra finansów Schaueble, nie była mile widziana na Kremlu, ale nie doprowadziła do nadmiernych obciążeń współpracy RFN z Rosją. Największe implikacje dla współpracy umacniających swoją pozycję międzynarodową Niemiec z Rosją miały przede wszystkim konflikt ukraińsko-rosyjski oraz częściowo kryzys migracyjno-uchodźczy. Można to z konieczności skrótowo przedstawić następująco:

- w nauce niemieckiej dominuje ocena Rosji jako państwa autorytarnego, którego przywódca W. Putin i jego najbliższe otoczenie podjęło interwencję zbroją przeciwko Ukrainie (Krym, Donbas, 2014) głównie z motywów wewnętrznych w celu legi- 
tymizacji władzy i zwiększenia poparcia dla siebie wśród Rosjan od początku 3-ciej kadencji prezydenckiej w 2012 r. W dalszej kolejności Putin i jego ekipa dążyły do osłabienia wpływów zachodnich na obszarze proradzieckim, głównie w celu przekreślenia możliwości przystąpienia perspektywicznego Ukrainy i Gruzji do NATO oraz strategicznego umocnienia w Rosji w rejonie Morza Czarnego, Śródziemnego i na Zakaukaziu. Putin nie ułatwi Merkel i Holllande’owi szybkiego rozwiązania kryzysu ukraińsko-rosyjskiego bez uzyskania określonych gwarancji dla utrzymania własnych wpływów na Ukrainie i całym obszarze proradzieckim;

- wzrost roli międzynarodowej Niemiec wzmacnia również zabiegi Kremla o umocnienie swoich wpływów w RFN, którą uważa za ważny przyczółek oddziaływania na UE. Wśród sił politycznych sympatię i gotowość do współpracy z Kremlem wyrażają zarówno czołowi politycy współrządzących - CSU i SPD, jak też opozycyjna Partia Lewicowa i wzrastającą w siłę populistyczna AfD oraz współpracujący z nią główny ruch protestu antyislamskiego w Niemczech - PEGIDA. Coraz większe znaczenie mają w Niemczech media rosyjskie w języku niemieckim, w tym telewizja internetowa „Sputnik” i inne. Oligarchowie z kręgów Putina założyli w 2016 r. między innymi w Berlinie rosyjską fundację naukowo-edukacyjną dla otwartych dyskusji na aktualne tematy polityczne i społeczno-kulturalne dla zainteresowanych grup mieszkańców stolicy (Putin laesst Denkfabrik in Berlin gruenden, 2016). Od 2015 r. wznowił działalność Dialog Petersburski jako ważne forum intensywnych kontaktów, wymiany poglądów oraz realizacji różnych projektów niemiecko-rosyjskich (Auf dem Weg nach Moskau, 2016);

- przedstawiciele gospodarki niemieckiej, a zwłaszcza jej Komitet Wschodni - występują zdecydowanie na rzecz zniesienia sankcji gospodarczych UE wobec Rosji. Doprowadzają one w Niemczech zarówno do spadku wymiany handlowej z Rosją, przynosząc duże straty zwłaszcza firmom małym i średnim. W sumie za zniesieniem zachodnich sankcji gospodarczych wobec Rosji wiosną 2016 r. było w Niemczech łącznie 61\% ankietowanych, w tym całkowicie 35\%, a częściowo 26\% (Meinung zu den Sanktionen gegen Russland, 2016);

- dyplomacja niemiecka często formułowała postulat, iż Rosja jest potrzebna do zwalczania terroryzmu międzynarodowego. Niemcy wraz z Rosją czynnie współpracowały w latach 2014-2015 między innymi w rozmowach 5+1 (stali członkowie Rady Bezpieczeństwa + Niemcy) w Wiedniu odnośnie przywrócenia dialogu politycznego i zakończenia wojny domowej w Syrii. Równocześnie kanclerz Merkel często krytykowała Rosję za łamanie praw człowieka. Dyplomacja rosyjska i osobiście minister spraw zagranicznych S. Ławrow postanowili wykorzystać sprawę rzekomego gwałtu na 13-letniej dziewczynce niemieckiej „Lizie” rosyjskiego pochodzenia $\mathrm{w}$ Berlinie, puszczając $\mathrm{w}$ ruch machinę propagandową w mediach rosyjskich w Rosji oraz na terenie RFN bez odczekania na wyniki formalnego śledztwa policji berlińskiej, która całkowicie wykluczyła gwałt. Do tego celu część liderów Niemców rosyjskich, posiadających obok obywatelstwa niemieckiego również paszporty rosyjskie, zmobilizowało nawet kilkanaście tysięcy demonstrantów wśród Niemców rosyjskich przed Urzędem Kanclerskim w Berlinie oraz w innych miastach niemieckich. Sprawa powyższa spowodowała wymianę not dyplomatycznych między Berlinem a Moskwą (por. Angeblich vergewaltigte 13-jaehrige, 2016). 
Reasumując można stwierdzić, iż Niemcy odgrywają ważną rolę w kontaktach dyplomatycznych, politycznych, społecznych i gospodarczych z Rosją, stojąc zdecydowanie po stronie swoich partnerów i sojuszników zachodnich. Pozwoliło to wprawdzie na doprowadzenie przez kanclerz Merkel i prezydenta francuskiego Hollande'a do zawarcia rozejmu w Donbasie 12 marca 2015 r., ale nie przyczyniło się to do przewrócenia tam pokoju. W tej sytuacji rząd CDU/CSU/SPD kanclerz Merkel popierała konsekwentnie sankcje UE wobec Rosji od wiosny 2014 r., które jednak nie są w Niemczech popularne wśród społeczeństwa i przynoszą znaczne szkody gospodarce niemieckiej. Wykorzystując liczne formy kontaktów oraz kooperacji niemiecko-rosyjskiej Kreml rozbudował w Niemczech własny aparat propagandowy dla instrumentalizacji własnych celów politycznych.

Część polityków chadeckich, zwłaszcza z CDU na czele z kanclerz Merkel, zaostrza w ostatnim czasie swoje stanowisko wobec Rosji. W Białej Księdze z 13 lipca 2016 r. rząd RFN podtrzymuje wprawdzie długofalowo chęć traktowania Rosji jako „partnera strategicznego" Niemiec. Jednak ze względu na aneksję Krymu i poparcie dla separatystów w Donbasie aktualna strategia Niemiec wobec Rosji opiera się na „wiarygodnym odstraszaniu” oraz umacnianiu własnej ,zdolności obronnej”, jak też podtrzymywaniu ,gotowości do dialogu” (Weissbuch, 2016, s. 25).

Polska jako bliski sąsiad, sojusznik w NATO (od 1999 r.) oraz partner w UE (od 2004 r.) nie posiadała formalnie statusu ,,partnera strategicznego" Niemiec, doprowadzając jednak w drugiej dekadzie XXI w. - po załagodzeniu kontrowersji wokół obciążeń historycznych oraz regulacji wielu spraw trudnych w wymiarze dwu- i wielostronnym - do zacieśnienia i pogłębienia z Berlinem dobrosąsiedzkiej i przyjaznej współpracy stosownie do regulacji traktatowych z 1991 r. (zob. Barcz, Tomala, 1992). Od początku transformacji systemowej w Polsce po 1989 r. większość rządów Rzeczypospolitej Polskiej (RP) zabiegało o poparcie zjednoczonych Niemiec dla procesu jej integracji z UE przy równoczesnym dążeniu do zabezpieczenie swoich interesów państwowo-narodowych. Dysproporcje rozwojowe i asymetrie ekonomiczne, demograficzne i inne na korzyść Niemiec, doprowadziły stopniowo w ciagu XXI w. do sygnalizowanego już wyżej wzrostu ich roli i pozycji międzynarodowej, zwłaszcza zaś w UE. Spowodowało to powstanie dla Polski w drugiej dekadzie XXI w. określonych implikacji, które można w uproszczeniu oraz syntetycznie sprowadzić do różnic w podejściu dwóch rządów RP: a) koalicji Platformy Obywatelskiej (PO)/Polskiego Stronnictwa Ludowego (PSL) do jesieni 2015 r. oraz b) nowego rządu PiS od października 2015 r. - do współpracy z Niemcami w UE (por. obszernie Cziomer, 2016c).

- Koalicja PO/PSL (2007-2015) zmierzała po złagodzeniu lub zaniechaniu sporów bilateralnych doprowadzić do systematycznej rozbudowy współpracy z Niemcami w ramach UE. Szczegółowy program na temat współpracy został ostatecznie wypracowany w obszernym dokumencie po konsultacjach polsko-niemieckich w Warszawie z okazji 20. rocznicy podpisania układu o dobrym sąsiedztwie i przyjaznej współpracy 21 czerwca 2011 r. W jego punkcie 9 określono bardzo szeroko zakres współpracy oraz konkretne projekty współpracy Polski z Niemcami w UE (zob. Program wspótpracy, 2011). Z licznych wypowiedzi i deklaracji premiera D. Tuska, a zwłaszcza ministra spraw zagranicznych R. Sikorskiego, wynikało, iż Polska jest skłonna uznać przywództwo Niemiec w UE w celu rozwiązania kryzysu strefy euro 
w zamian za dopuszczenie jej do ścisłego kręu decyzyjnego ,państw trzymających władzę" w UE. Należy podkreślić, iż Polska ani nie spełniała kryteriów konwergencji UE, ani też wobec oporu większości społeczeństwa, opozycji PiS oraz trudności prawno-konstytucyjnych, nie miała realistycznej perspektywy przystapienia do strefy euro. W okresie rządów koalicji PO/PSL do 2015 r. Polska była największym beneficjentem środków pomocowych UE, w tym również w perspektywie do $2020 \mathrm{r}$. Równocześnie przy dużym poparciu kanclerz Merkel, premier Tusk został w 2014 r. wybrany na przewodniczącego Rady Europejskiej (por. Malinowski, 2014).

- Stanowisko nowego rządu PiS do współpracy z Niemcami w UE od jesieni 2015 r. było ambiwalentne. Wynikało to z jednej strony z kontrowersji polsko-niemieckich w aspekcie bilateralnym i unijnym pierwszego rządu koalicyjnego PiS/Samoobrona/Liga Polskich Rodzin (2005/2006-2007), jak też ogólnego zarzutu PiS jako partii opozycyjnej do 2015 r. o generalnym dążeniu Niemiec do dominacji w UE. Równocześnie jednak dostrzegano potrzebę utrzymania korzystnej współpracy gospodarczej z Niemcami. Kolejnym problemem spornym było kwestionowanie przez rząd PiS razem z krajami Grupy Wyszehradzkiej i innymi państwami UE forsowanej przez Merkel i Komisję Europejską obowiązkowej dyslokacji nielegalnych uchodźców we wszystkich krajach członkowskich UE. W expose na temat polityki zagranicznej 29 stycznia 2016 r. minister spraw zagranicznych W. Waszczykowski na priorytetowym miejscu umieścił Wielką Brytanię jako partnera strategicznego Polski, przypisując Niemcom jedynie funkcję ważnego sąsiada i pierwszoplanowego partnera gospodarczego. W toku dalszych spotkań i konsultacji na różnych szczeblach między kwietniem a czerwcem 2016 r. doszło do częściowego zbliżenia stanowisk w niektórych sprawach spornych. Z okazji 25 . rocznicy podpisania wspomnianego już wyżej Traktatu polsko-niemieckiego o dobrym sqsiedztwie i przyjaznej wspótpracy obie strony zdecydowały się jedynie na wydanie Wspólnego oświadczenia ministrów spraw zagranicznych RP i RFN z 22 czerwca 2016 r., odnoszących się zarówno do kwestii bilateralnych, jak też unijnych, z których przytaczam tylko kilka najistotniejszych dla naszej analizy:

- ,przez 25 lat od 1991 r. Traktat doprowadził do zaufania i zbliżenia między Polakami i Niemcami we wszystkich dziedzinach, dzięki czemu stali się »dobrymi sąsiadami« i »bliskimi partnerami«;

- mniejszość niemiecka w Polsce i Polacy w Niemczech winni »zgodnie z traktatami«, mieć możliwość uczenia się języka ojczystego, co winno być w kręgu zainteresowań Rządów;

- w obecności prezydentów utworzono »Polsko-Niemiecką Grupę Refleksyjnąu, która będzie analizować »międzynarodowy kontekst stosunków polsko-niemieckich w wymiarze europejskim i globalnym«;

- dynamiczna współpraca gospodarcza jest »podporą współpracy obu krajów«. Obroty towarowe wzrosły 12 razy z 8 do 96 mld euro w latach 1991-2015, a skumulowane inwestycje niemieckie wzrosły do 28 mld euro, tworząc ok. 300000 miejsc pracy w Polsce;

- Polska i Niemcy wnoszą wkład w umocnienie bezpieczeństwa w ramach NATO i będą kierować jego szpicą - RFN (2019), Polska (2020), opowiadając się za »konstruktywnym dialogiem« z Rosją; 
- Polska i Niemcy zmierzają do przezwyciężenia wszelkich wyzwań stojących przed UE, dążąc do utrzymania jej jedności. Zmierzają one także do kształtowania aktywnej polityki wschodniej UE, poszukując również konstruktywnego dialogu z Rosją w rozwiązaniu konfliktu we wschodniej Ukrainie;

- kryzys uchodźczy jest jednym z najważniejszych wyzwań dla Europy, w którego rozwiązywaniu UE nie powinna się podzielić. Rozwiązania należy szukać głównie w utworzeniu Europejskiej Straży Granicznej, realizacji porozumienia z Turcją i innymi partnerami zewnętrznymi” (Wspólne oświadczenie, 2016).

Ogólnie można przyjąć, iż powyższe fragmenty „wspólnego oświadczenia” MSZ RP i RFN posiadają charakter deklaratywny i otwierają możliwość pragmatycznej współpracy na przyszłość.

\section{Konkluzja}

Z przeprowadzonej analizy wynika, iż Niemcy jako czołowe europejskie mocarstwo geoekonomiczne o interesach globalnych umacniały systematycznie w drugiej dekadzie XXI w. swoją rolę i pozycję międzynarodową. W tym celu ośrodki decyzyjne rządu federalnego wspólnie ze środowiskami naukowymi od 2012 r. wypracowały, rozbudowały i wdrażały stopniowo tzw. koncepcję współkształtowania (Gestaltungskonzept) polityki zagranicznej i bezpieczeństwa Niemiec. Znalazło to między innymi odzwierciedlenie $\mathrm{w}$ praktycznym angażowaniu się Niemiec $\mathrm{w}$ rozwiązywanie takich złożonych kryzysów UE jak: zadłużenia strefy euro od 2010 r., rosyjsko-ukraińskiego do 2014 r. oraz nielegalnej migracji do UE od drugiej połowy w 2015 r. Sprawa ostatecznego rozwiązania powyższych kryzysów pozostaje wciąż otwarta w kontekście narastania nowych wyzwań w wymiarze globalnym i UE. Dlatego też wzrost roli międzynarodowej Niemiec od początku XXI posiada szereg złożonych implikacji oraz wyzwań dla współpracy z Rosją i Polską, ponieważ ekipa rządząca w Berlinie na czele $\mathrm{z}$ kanclerz Merkel nie jest w stanie w każdej sytuacji przeforsować założone przez siebie cele.

\section{Bibliografia}

Angeblich vergewatigte 13-jaehrige. Russland nutz „Fall Lisa” fuer Retorkutsche am Westen (2016), 30.01.2016, http://www.tagesspiegel.de/politik/angeblich-vergewaltigte-13-jaehrige-russland-nutzt-fall-lisa-fuer-retourkutsche-am-westen/12900562.html.

Barcz J., Tomala M. (1992), Polska-Niemcy: Dobre sqsiedztwo i przyjazna wspótpraca, Warszawa.

Bohr E., Krauze A. (2011), 20 Jahre deutsche Einheit. Bilans und Perspektiven.

Chronik Deutschland, 1949-2014 (2014), w: Der neue Fischer Weltalamanach, Frankfurt Am Main.

Cziomer E. (2010), Polityka zagraniczna Niemiec w dobie nowych wyzwań globalizacji, bezpieczeństwa międzynarodowego oraz integracji europejskiej po 2005 roku, Warszawa.

Cziomer E. (2013), Rola Niemiec w kryzysie strefy euro, Kraków.

Cziomer E. (2014), Teoria i praktyka decydowania w polityce zagranicznej Niemiec na przyktadzie roli kanclerz Angeli Merkel w kryzysie strefy euro w latach 2010-2013, w: Teoria i praktyka 
stosunków międzynarodowych. Dziedzictwo intelektualne profesora Ziemowita Jacka Pietrasia, red. M. Pietraś, H. Dumała, B. Surmacz, A. W. Ziętek, Wydawnictwo UMCS, Lublin.

Cziomer E. (2015), Niemcy wobec geopolitycznego wymiaru kryzysu ukraińskiego 2013-2015, „Krakowskie Studia Międzynarodowe”, nr 2 (XII), Kraków, s. 39-56.

Cziomer E. (2016a), Przesłanki i wyzwania poszukiwania nowej roli międzynarodowej Niemiec $w$ dobie narastajacych kryzysów Unii Europejskiej - wybrane problemy badań i praktyki politycznej w XXI wieku, „Krakowskie Studia Międzynarodowe”, nr 1, Kraków.

Cziomer E. (2016b), Wyzwania wewnętrzne i międzynarodowe nielegalnej migracji do UE na przykładzie Niemiec w latach 2015-2016, w: Wyzwania bezpieczeństwa i wspótpracy międzynarodowej ze szczególnym uwzględnieniem nielegalnej migracji. Państwo, gospodarka, społeczeństwo, red. B. Molo, Kraków (złożone do druku).

Cziomer E. (2016c), Miejsce Polski w poszukiwaniach nowej roli i odpowiedzialności międzynarodowej Niemiec w drugiej dekadzie XXI wieku, w: Stosunki Polski z mocarstwami w drugiej dekadzie XXI wieku, red. J. Czornik, M. Lakomy, M. Stolarczyk, Katowice (złożone do druku).

Deutschlands Zukunft gestalten (2013), Koalitionsvertrag zwischen CDU, CSU und SPD vom 27.11.2013, 18 Legislaturperiode, Berlin.

Fluechtingszenarien Fuenf Fluechtklingsszenarien (2016), „Die Welt”, 17.03.2016, http://www.welt. de/wirtschaft/article153372386/Fluechtlinge-koennten-bald-ueber-die-Kaukasus-Routekommen.html.

Frantzscher M. (2014), Die Deutschland - Illusion. Warum wir unsere Witschaft ueberchaetzen und Europa brauchen, München.

Gauck J. (2014), Deutschlands Rolle in der Welt: Anmerkungen zu Verantwortung, Normen und Bündnissen, München, Rede 31.01.2014, s. 1-9, www.bundespraesident.de.

Germany's benefis from the greek crisis (2015), „IWH-Studie”, 20.04.2015, http://www.iwh-halle. $\mathrm{de} / \mathrm{d} /$ publik/iwhonline/io_2015-07.pdf, 21.03.2016.

Gestaltungskonzept der Bundesregierung, Globalisierung gestalten - Partnerschaft ausbauen - Verantwortung teilen. Konzept der Bundesregierung (2012), 8.02.2012, http://www.auswaertiges-amt.de/cae/servlet/contentblob/608384/publicationFile/169965/Gestaltungsmaechtekonze.pdf, 20.04.2015.

Gipfel zur Fluechtkingsfrage. Wie Europa Staaten zum Tuerkei - Deal stehen (2016), „Handelsblatt”, 17.03.2016, http://www.handelsblatt.com/politik/international/eu-gipfel-zur-fluechtlingskrise-wie-europas-staaten-zum-tuerkei-deal.

Griechenlanderhaeltneuen Miliardenkredit(2015),,,Spiegel-Online”, 2.12.2015, http://www.spiegel. de/wirtschaft/soziales/griechenland-esm-ueberweist-naechsten-milliardenkredit-a-10692, 21.03.2016.

Hellmann G. (2016), Zwischen Gestaltungsmacht und Hegemoniefalle. Zur neuesten ,neuen deutschen Aussenpolitik”, „Aus Politik und Zeitgeschichte”, nr 28-29, Berlin.

Hellmann G., Jacobi D., Urrestararazu U. (red.) (2015), ,,Frueher, entschiedener und substantieler?” Die neue Debatte über Deutschlands Aussenpolitik, Wiesbaden.

Illing F.(2013), Deutschland in der Finanzkrise. Chronologie der deutschen Wirtschaftspolitik 2007-2012, Wiesbaden.

Kaim M., Perthes V. (2012), Herausforderungen der deutschen Außen- und Sicherheitspolitik bis 2030: Gestaltung in der turbulenten Welt, http://www.swp-berlin.org/fileadmin/contents/products/fachpublikationen/121016_ZfAS_Deutschland2030_prt_kim.pdf, 12.02.1016.

Katsiopulis C. (2015), Der schmale Grat zwischen Führung und Fuehrer. Die deutsche Führungsrolle in der Eurokrise aus griechischer Sicht, w: Deutsche Aussenpolitik und internationale Führung. Ressourcen, Praktikum in einer veränderten Euorpaeischen Union, red. S. Harnisch, J. Schild, Baden-Baden. 
Leyen U. von der (2014), Rede anlaesslich der Muechner Sicherheitzkonferenz Am 01.02.2014, http://www.nato.diplo.de/contentblob/4123416/Daten/3885836/redevdleyensiko2014.pdf, 16.03.2016.

Malinowski K. (2009), Przemiany niemieckiej polityki bezpieczeństwa, Poznań.

Malinowski K. (2014), Polska i Niemcy w Europie (2004-2014). Różnice interesów i konsekwencje, Poznań.

Meinung zu den Sanktionen gegen Russland (2016), „Internationale Politik”, nr 3, Mai/Juni 2016, https://zeitschrift-ip.dgap.org/de/ip-die-zeitschrift/archiv/jahrgang-2016/mai-juni/meinungen-zu-den-sanktionen-gegen-russland.

Meister S. (2014), Russland Agression - ein Zeichen innerer Schwaeche, w: Aussenpolitik mit Autokratien, red. J. Branl, W. Merkel, E. Sandscheider, Berlin-Boston-Muenchen.

Neue Macht. Neue Verantwortung. Elemente einer deutschen Aussen- und Sicherheitspolitik für eine Welt im Umbruch. Ein Papier der Stiftung Wissenschaft und Politik (SWP) und des German Marshall Fund on the United States (GFM) (2013), Oktober, Berlin, http://www.swp.de, 22.03.2016.

Program wspótpracy przyjęty przez Rząd Rzeczypospolitej Polskiej i Republikę Federalnq Niemiec z okazji 20. rocznicy podpisania Traktatu między RP i RFN (2011), Warszawa, 21.06.2011, https://www.premier.gov.pl/wydarzenia/aktualnosci/deklaracja-i-program-wspolpracypolski-i-niemiec-przyjete, 30.06.2016.

Putin laesst Denkfabrik in Berlin gruenden (2016), 30.06.2016, http://www.welt.de/politik/deutschland/article156676468/Putin-laesst-in-Berlin-riesige-Denkfabrik-gruenden.html.

Review 2014 - Die Schlussfolgerungen (2015), http://www.auswaertiges-amt.de/DE/AAmt/Review2014/Ueberblick/Text_node.html, 11.02.2016.

Rinke A. (2014), Die Genese der ,,neuen deutschen Aussenpolitik, „Internationele Politik”, Juli/August, Berlin.

Schulden und Flüchtlinge. Grirchnelands Doppelkrise (2016), „Spiegel - Online”, 27.02.2016, http:// www.spiegel.de/wirtschaft/soziales/griechenland-schon-im-maerz-2016-pleite-a-1079485. html, 18.04.2016.

Steinmeier F. W. (2014), Rede anlaesslich der Muechener Sicherheitskonferenz am 01.02.2014, http:// www.auswaertiges-amt.de/DE/Infoservice/Presse/Reden/2014/140201-BM_M\%C3\%BC SiKo.html, 22.03.2016.

Weissbuch 2016. Zur Sicherheitspolitik und zur Zukunft der Bundeswehr (2016), Berlin.

Wspólne oświadczenie ministrów spraw zagranicznych Rzeczypospolitej Polskiej i Republiki Federalnej Niemiec z okazji 25. rocznicy Traktatu między Rzczapospolita Polska a Republika Federalnq Niemiec o dobrym sqsiedztwie i przyjaznej wspótpracy (2016), 22.06.2016, https:// www.msz.gov.pl/resource/141c17f8-522f-46e7-83dd-61694af3d769:JCR, 3.07.2016.

Zięba R. (red.) (2004), Wstęp do teorii polityki zagranicznej państwa, Wydawnictwo A. Marszałek, Toruń.

\section{Streszczenie}

Artykuł koncentruje się w ujęciu syntetycznym oraz problemowym na ukazaniu implikacji wzrostu międzynarodowej roli Niemiec dla współpracy z Rosją i Polską w dobie globalizacji oraz kryzysów UE. W pierwszej części przedstawia teoretyczne i praktyczne aspekty kształtowania koncepcji nowej roli międzynarodowej Niemiec, tzw. koncepcji współkształtowania (Gestaltungskonzept) polityki zagranicznej i bezpieczeństwa. Druga część podejmuje ogólną ocenę roli Niemiec w próbach rozwiązywania wybranych kryzysów UE - zadłużenia strefy euro od 2010 r., konfliktu rosyjsko-ukraińskiego od 2014 r. oraz masowego napływu nielegal- 
nych migrantów do UE od przełomu sierpnia/września 2015 r. Trzecia część koncentruje się na analizie implikacji nowej roli międzynarodowej Niemiec dla współpracy z Rosją i Polską. Konkluzja artykułu brzmi - wzrost roli międzynarodowej Niemiec od początku od drugiej dekady XXI w. miał pozytywne i negatywne następstwa dla współpracy Niemiec z Rosją i Polską.

Słowa kluczowe: wzrost międzynarodowej roli Niemiec, kryzysy UE, implikacje, współpraca, Rosja, Polska

Selected consequences of the increased international role of Germany for the cooperation with Russia and Poland during the era of globalization and crises of the European Union in the $21^{\text {st }}$ century

\section{Summary}

The paper focuses on synthetic and comprehensive presentation of the implications of the increasing international role of Germany for cooperation between Poland and Russia, in times of globalization and EU's crises. The first part of the paper showcases the theoretical and practical aspects of the concept formation of Germany's new international role, the so-called design concept (Gestaltungskonzept) of the foreign and security policies. The second part provides an overall assessment of Germany's role in the attempts to resolve chosen EU's crises - the European debt crisis of 2010, the Russian-Ukrainian conflict of 2014 as well as the large influx of illegal immigrants to the EU ever since the turn of August and September 2015. The third part concentrates on the analysis of the implications of the new role in the international arena assumed by Germany for the Polish and Russian cooperation. The conclusion of the paper is following: the growing international role of Germany in the second decade of the $21^{\text {st }}$ century has had both positive and negative impact on the cooperation between Poland and Russia.

Key words: growth of the international role of Germany, EU-crisis, implications, cooperation, Russia, Poland 